\title{
Performance management of agricultural entrepreneurship
}

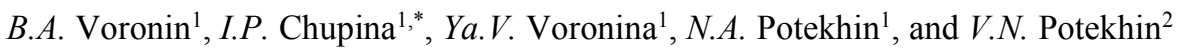 \\ ${ }^{1}$ Ural State Agrarian University, Yekaterinburg, Russia \\ ${ }^{2}$ Ural State University of Economics, Yekaterinburg, Russia
}

\begin{abstract}
In the field of economics, the concept of "efficiency is traditionally interpreted as the ratio of the volume of products produced and the costs incurred for obtaining these products. This definition of efficiency is similar to the concept of profitability of production, although in practice in agriculture the concept of "efficiency" is a more complex category, since it requires the integration of many factors in order to obtain positive results in production. Agrarian entrepreneurs must effectively and efficiently use land resources as the main means of production. In the same row there are biological resources - agricultural plants, farm animals, poultry and other biological objects. In modern conditions, agricultural entrepreneurship cannot be carried out without new technology, equipment and other means of mechanization and intellectualization of agricultural activities. To obtain the results of effective management, scientific and technological support of entrepreneurship in the agricultural sector will be required. As can be seen from the above factors, the concept of "efficiency" in the agrarian economy includes in its definition a set of relations, the implementation of which is necessary for the functioning of production in market conditions.
\end{abstract}

\section{Introduction}

The topic of researching the problem of the effectiveness of agrarian entrepreneurship is relevant, because ineffective agribusiness negatively affects the functioning of an entrepreneurial organization, up to its bankruptcy and liquidation. The study of the topic of managing the efficiency of agricultural entrepreneurship in the Russian Federation has not yet received adequate development, and for this reason it is advisable to develop this topic, which is supposed to be carried out within the framework of this article.

The scientific novelty of this research is associated with the analysis of the concept of "efficiency" of agriculture and agaric entrepreneurship. The authors also propose a version of state support, which boils down to the production of agricultural products on limited land areas.

The purpose of researching the topic of this scientific article is to identify the effectiveness of scientific, technological, economic and social development of agriculture and subjects of agricultural entrepreneurship. The objective of the research is to analyze the

\footnotetext{
${ }^{*}$ Corresponding author: irinacupina716@gmail.com
} 
actual state of the efficiency of agricultural activities in the context of transformations in the agrarian economy.

The theoretical significance of the work is due to the possibility of using materials for the development of economic theory and the theory of agricultural economics. The practical significance lies in the possibility of using the material in the agricultural management system, research work and in the educational process in institutions of agricultural education.

By definition of the author Stolyarova O.A. in his article "The role of fixed assets in improving the efficiency of agricultural production" [1] "efficiency" is an indicator of the ability of a system (organization, department, person) to achieve the required result with an economical use of resources to achieve it. Performance and Cost-Effectiveness Indicators are KPIs.

The efficiency of agribusiness is ensured by technical efficiency and economic efficiency [2]. One of the important indicators of the efficiency of agricultural activities is the increase in labor productivity. This is described in detail in the article by V.T. Vodyannikov. "Scientific and technical process and efficiency of agricultural production" [3].

The problems of the effectiveness of the formation and development of human capital of an agricultural organization [4 - 6], and the agricultural management system in modern Russia [7-9] are described in scientific articles published by the authors of this article in the journal "Agrarian Bulletin of the Urals" for 2019, as well as in other scientific papers published in the journals Scopus and Web of Science [10-13]. But in these articles, the option of state support is not considered, where the production of agricultural products on ecologically clean lands is taken as a basis and technogenically contaminated lands are excluded.

\section{Materials and Methods}

The article uses materials from the state statistics bodies of the federal and regional levels. Methods of analysis and synthesis were used to summarize the research results. The forecasting method is used in the proposals and recommendations of the authors on the formation of a state order for agricultural products.

\section{Results and Discussion}

Efficiency management in agricultural entrepreneurship is associated with the management of work and resources, and for this, organizational and economic conditions must be created, consisting of goals, objectives, marketing of manufactured products (products). Based on this, the volume of means of production and objects of labor should be determined on the basis of which it is possible to obtain the planned result. When planning the effectiveness of agricultural entrepreneurship, a complex of factors and features of agricultural production should be taken into account.

First, the dependence of agriculture on natural and climatic conditions, which can be a key risk for agricultural activities (droughts, floods, wildfires and other natural phenomena).

Secondly, the use of land plots as the main means of production, as a rule, from agricultural land, which implies their rational use and conservation as an object of nature and a natural resource.

Great importance is attached to the preservation of soil fertility while reducing the volume of application of chemical synthetic preparations, which will affect the ecologization of agriculture and the quality of the raw materials and food produced. 
Thirdly, it should be borne in mind that a characteristic feature of agriculture is the seasonality of production, which practically cannot be regulated, since it is associated with the cycle of growing crops and, in part, farm animals, poultry, bees, aquaculture and other species. For this reason, the work of machine operators using tractors, combines and other mechanisms is also seasonal.

Fourthly, for agricultural entrepreneurs, the complexity is represented by the spatial dispersion of production (fields, farms) and other objects of production and economic infrastructure, which is reflected in transport costs and other non-production costs of an agricultural organization.

Fifth, at present, the problem of human capital is manifested, on the one hand, due to the aging of employees of existing organizations and enterprises, and on the other hand, due to the lack of young people in rural settlements who are ready to work in agriculture and the agro-industrial complex.

Sixth, many types of agricultural products are perishable, and in this regard, individual entrepreneurs are mastering the processing of agricultural raw materials, which will require the organization of a new production that requires the availability of specialists, the acquisition of technological, refrigeration, laboratory and other equipment and, in general, the creation of the necessary conditions for production of high-quality and safe food products. It is also necessary to have storage facilities that meet veterinary and sanitary standards and requirements.

Seventh, the development of agribusiness cannot be obtained on the basis of past methods, technologies and production conditions. In this regard, agricultural entrepreneurs should pay increased attention to the introduction of scientific achievements in crop and livestock production, mastering the current practices of conducting "smart" agriculture through digitalization, robotization and other areas of the modern technological order.

The listed individual factors should be taken into account by agricultural entrepreneurs in the organization and development of agribusiness. And if they are implemented in practice, then this will ensure an increase in the efficiency of agricultural production and its effectiveness and efficiency. Management of the efficiency of agricultural entrepreneurship is an important change that affects the development of not only agricultural enterprises, but also small businesses to adapt to changing market conditions and increase the competitiveness of products.

It has already been stated in the article that human potential plays the most important role in performance management. The ability to quickly adapt to changing market conditions - this is the efficiency of agricultural entrepreneurship. A modern leader must understand not only the natural and agricultural sciences, but also have information about new modernization processes. Which he himself can apply in his business. The success of an enterprise depends on the professional abilities of a businessman - a leader. Agribusiness primarily performs the function of increasing tax revenues to the local budget. Also, agrarian entrepreneurship contributes to solving the problem of employment in rural areas.

Along with the production and technological requirements for the efficiency of agricultural activities, economic indicators should also be taken into account, such as profitability, labor productivity, lending, the use of state support through a system of subsidies, an integrated part of costs, subsidies, tax incentives and other economic indicators.

For this, the authors propose to apply one of the options for state support, the essence of which is the production of agricultural products on limited land areas, where technogenically contaminated lands are excluded. State support should be distributed among the subjects of the Ural Federal District, which takes into account the agro-resource capabilities of each subject when expanding the guaranteed state-regional order for agricultural products produced in the region. At the same time, the agricultural credit 
subsystem (ICS) and the agricultural wholesale and retail subsystem (OSRP) are developing.

The justification for the level of state support for the transition to a state-regional order is presented in the calculations, which take into account a possible reduction in the sowing area.

$F_{2}=0,01(100-25) \times 5385$ thousand hectares $=4038.7$ thousand hectares where $\mathrm{F}_{2}$-is the sown area after a $25 \%$ reduction in technologically disturbed lands in the region.

Next, consider the volume of gross domestic product production in the region to solve the problem of self-sufficiency in agricultural products, the share of which in the region is $30 \%$ :

$$
\begin{gathered}
V P_{2}=0,01 \times 130 \times V P_{1}=1,3 V P_{1}=1,3 \times 233,6 \text { billion rubles } \\
=303,68 \text { billion rubles }
\end{gathered}
$$

Table 1. The effectiveness of organizational and legal forms of management in the agricultural sector of the Sverdlovsk region

\begin{tabular}{|l|c|c|c|c|}
\hline $\begin{array}{c}\text { Organizational and } \\
\text { legal forms }\end{array}$ & $\begin{array}{c}\text { Number of } \\
\text { organizations, } \\
\text { units }\end{array}$ & $\begin{array}{c}\text { Gross production } \\
\text { per } 100 \text { hectares } \\
\text { of agricultural } \\
\text { land, thousand } \\
\text { rubles }\end{array}$ & $\begin{array}{c}\text { The cost of } \\
\text { marketable } \\
\text { products per } 100 \\
\text { hectares of } \\
\text { agricultural land, } \\
\text { thousand rubles }\end{array}$ & $\begin{array}{c}\text { Profitability for } \\
\text { the whole } \\
\text { enterprise } \\
\text { (without } \\
\text { subsidies), } \%\end{array}$ \\
\hline $\begin{array}{l}\text { Agricultural } \\
\text { production } \\
\text { cooperatives }\end{array}$ & 85 & 316,4 & 213,5 & 4,6 \\
\hline $\begin{array}{l}\text { Limited liability } \\
\text { companies }\end{array}$ & 25 & 449,4 & 308,4 & 3,8 \\
\hline $\begin{array}{l}\text { Closed joint stock } \\
\text { companies }\end{array}$ & 11 & 296,8 & 188,3 & 7,9 \\
\hline
\end{tabular}

Based on the data in Table 1, it follows that 100 hectares of agricultural land more than gross and marketable output was produced in agricultural organizations that have a "society with organic responsibility". This form of management has proven to be the most effective in ensuring food security.

At present, attention is paid to the development of exports of agricultural products, raw materials and foodstuffs, which, on the one hand, increases the profitability of agricultural production, and on the other hand, affects the increase in the cost of ensuring the export procedure, since there is a need to build a system of marketing, logistics and other elements in this area.

The listed approaches to the content of the concept of "efficiency of agricultural entrepreneurship" convince that it is necessary to form an efficiency management system, otherwise it is difficult to ensure the coordination of individual areas of development of agricultural entrepreneurship. The main mechanism for managing efficiency is efficiency, which can be managed through the organization of work, transforming resources into a result.

\section{Conclusion}

Entrepreneurship is a dynamic process that is tuned to independent and proactive activity, which is carried out at its own responsibility and risk. The success of entrepreneurship also depends entirely on the organizational skills of the entrepreneur. 
The essence of entrepreneurship is reflected in a number of features, the first of which is the independence of the entrepreneur and his economic independence in doing business. The entrepreneur himself decides for whom to produce his products, what to produce and by what technology. Freedom of action allows an entrepreneur to choose suppliers for his products and independently determine a market segment.

The second sign is the economic interest of the entrepreneur. Every entrepreneur dreams of getting the maximum profit. But the entrepreneur can get the maximum profit only if, in addition to his personal interests, he takes into account the interests of people who buy the products of this entrepreneur. Therefore, personal and public interests are closely intertwined here.

The third sign is responsibility for the results of their activities. If the profit is higher than production costs, then the result will be positive. The increase in profits stimulates the entrepreneur in personal interest and aims him at improving the results of his work.

The fourth sign is innovation and innovative development path. Fierce competition in the market is an incentive to develop creativity and new ideas for their products. Now the price plays a less significant role than the innovative idea for a new product. New forms of work organization, new technologies and non-standard solutions help the entrepreneur to withstand the competition.

And the last feature is entrepreneurial risk. Entrepreneurial activity is carried out in conditions of uncertainty and volatility of the market environment, so the end result may not always turn out to be positive. In addition, the main risk is the unpredictability of natural and climatic conditions. And the unpredictability of the final results will depend on this. It often happens that investments in production do not bring the desired result due to unpredictable weather conditions.

The peculiarities of the agricultural business are that the activity is related to agricultural production. And the main factor of production is land, which has a number of properties. One of these properties is the fact that land cannot be replaced by another means of production. Therefore, a prerequisite is the maintenance of soil fertility. Land plots are also different in terms of quality characteristics. These differences are manifested not only in soil fertility, but also in climatic conditions, in geographic zones. Therefore, the choice of crops grown depends entirely on these characteristics. These features predetermine the choice of specialization for each entrepreneur.

A distinctive feature of agricultural entrepreneurship from all other types of entrepreneurial activity is the fact that living organisms - plants and animals - are used for work. And the production process is associated with the growth and development of these living organisms. Therefore, for the successful conduct of an agricultural business, it is necessary to know the regularities of the productivity of living organisms.

Entrepreneurial activity in agricultural production is carried out in three socio economic structures - agricultural organizations, personal subsidiary plots and peasant farms.

If we look at agricultural organizations, then at present they are increasingly using updated technical means and modern technologies. As a result of the use of digital technologies, it is possible to predict a reduction in the workforce in these organizations in the future. Therefore, in order to prevent unemployment in these areas, there will be a need to create farms and personal subsidiary plots.

Already existing personal subsidiary plots are in the form of a business and belong to entrepreneurial activity, since the surplus of their production is sold on the market. They do not have the status of a legal entity, therefore, the activities of such entrepreneurship are more simplified. Also, personal subsidiary plots can provide various services to the population. For example, for the processing of personal plots. Personal subsidiary plots can be the basis for the formation of agricultural cooperatives. 
And if there are no hired workers in personal subsidiary plots, then hired workers are involved in farms. It is in the farms that they produce products that are now in increasing demand on the market. These are organic products that are made from environmentally friendly products and in areas not contaminated with radiation and other negative environmental factors.

A feature of agricultural entrepreneurship is the fact that it uses living organisms plants and animals. For the successful development of agrarian entrepreneurship, it is necessary to skillfully use in the production process not only agricultural machinery and the organization of production in general, but it is necessary to know the patterns of the productive development of plants and animals.

\section{References}

1. O.A. Stolyarova The role of fixed assets in increasing the efficiency of agricultural production, In the collection: Actual problems of financing and taxation of the agroindustrial complex in the context of globalization of the economy Collection of articles of the V All-Russian scientific and practical conference, $214-217$ (2018)

2. B.A. Voronin, I.P. Chupina, Ya.V. Voronina, Agrarian Bulletin of the Urals, 6, 59 (2019)

3. V.T. Vodyannikov, Technics and equipment for the village, 5, $44-48$ (2018)

4. M.A. Kantemirova, Economics and Entrepreneurship, 8, 200 - 202 (2018)

5. M.S. Kozlova, Forum of young scientists, 1, $340-343$ (2020)

6. A.V. Logacheva, Economy and society, 3, $365-368$ (2018)

7. Kh.E. Tekeeva, International Agricultural Journal, 63(1), 13 (2020)

8. S.Yu. Muslimova, Vector of Economics, 5(23), 52 (2018)

9. M.S. Kozlova, Forum of young scientists, 1, 340 - 343 (2020)

10. A.S. Gusev, O.I. Betin, E.A. Skvortsov, N.V. Ziablitckaia, N.V. Vashukevich, Y.V. Malkova, WSEAS Transactions on Environment and Development, 16, 820-830 (2020)

11. T.N. Medvedeva, I.A. Artamonova, I.N. Baturina, E.A. Farvazova, N.V. Roznina, E.G. Mukhina, IOP Conference Series: Materials Science and Engineering, 341, 120 (2019)

12. S.V. Kulaykin, A.K. Markov, Complex Systems: Innovation and Sustainability in the Digital Age, 1, 449-454 (2020)

13. K.P. Stozhko, D.K. Stozhko, Agrarian Bulletin of the Urals, 10 (201), 73-83 (2020) DOI: 10.32417/1997-4868-2020-201-10-73-83 (In Russian) 